\title{
Lexical Parametrization and Early Subjects in L1 Italian
}

\author{
Paolo Lorusso (Corresponding author) \\ (Università degli Studi di Firenze/CRIL Università del Salento), Contrada Turi, 270014 \\ Conversano (BA) Italy, Italy
}

Tel: 39-338-204-4883Ｅ-mail: pavlovlo@gmail.com

Received: Nov. 7, 2017 Accepted: November 17, 2017 Published: December 31, 2017

doi:10.5296/ijl.v9i6.12113 URL: https://doi.org/10.5296/ijl.v9i6.12113

\begin{abstract}
Italian is a pro drop language, since it allows subject drop and subject inversion. The pro-drop parameter is fixed early on (Orfitelli,2008), but both grammatical and informational factors might regulate the distribution of overt clausal subjects. On the grammatical side, the verb class influences the distribution of overt subjects: overt subjects in Italian are more likely to be found with unaccusative verbs (Lorusso, Caprin \& Guasti 2005). On the informational side, $1^{\text {st }}$ and $2^{\text {nd }}$ person pronouns are more likely to e dropped than $3^{\text {rd }}$ person NPs because the latter are more informative (Serratrice, 2005): $1^{\text {st }}$ and $2^{\text {nd }}$ ab ne recovered by the discourse, while $3^{\text {rd }}$ persons are totally event anchored and have to be identified referentially within the linguistic stimuli. The parametric differences encoded in the lexical items, for example the unaccusative vs unergative distinction for verbs or the person 'informative' morphology, influence the subject drop in Italian: we propose a Lexical Parametrization account (Manzini \& Wexler 1987) for subject drop in Italian, since the characteristic of lexical items influence the likelihood of appearance of an overt syntactic structure. Furthermore the distribution of indefinite postverbal subjects found just with unaccusatives in early stages of acquisition of Italian (Lorusso, 2014) confirms that the lexical characteristics of both the subject NPs and the verbs (in a subset relation with other NPs and verbs respectively) determine the parametric overt variation across the different stage of the acquisition of Italian, as Lexical Parametrization predicts.
\end{abstract}

Keywords: pro drop, Acquisition, Lexical Parametrization, verb classes, L1, Italian, person split 


\section{Introduction}

In this paper we will show that the distribution of overt subjects in Italian is linked to the morpho-syntactic features of the lexical elements found in each sentence. Italian is a pro-drop language which parametrically allows the subject drop. Overt subjects in Italian are more likely to be found with unaccusative verbs (Lorusso, Caprin \& Guasti 2005) in postverbal position and with $3^{\text {rd }}$ person indefinite subject (Lorusso 2014). This pattern of distribution of overt subjects seems to be generated by the parametric variation across the lexical items that are inserted in the morpho-syntactic derivation (Chomsky 2001, Borer 1984, Manzini \& Wexler 1987, Wexler \& Manzini, 1987). The Lexical Paremetrization Hypothesis (Manzini \& Wexler 1987, Wexler \& Manzini, 1987) seems to be at work in the acquisition of Italian since the parametric variation between lexical items influence the data of the early spontaneous productions. In this respect we propose a corpus analysis of the spontaneous speech of four children and their parents and caregivers. We will show that both adults and children use overt subjects depending on the morpho-syntactic features of the lexical items involved in the sentences. Although the pro-drop parameter is set early on, different lexical and morpho-syntactic features influence the distribution of overt subjects. Indefiniteness has a central role within the different lexical parameters that interact in the determining the pattern of distribution of overt subjects. The definiteness of the subject DPs represents a subset condition for the postverbal subject with unaccusatives especially in child grammar. In section 2 we will propose the general data about the subject drop in the spontaneous speech in Italian. Italian verbal agreement paradigm expresses the $\varphi$-features necessary for local recovery of the content of dropped subjects, subject drop is acquired early on by children (Hyams, 1986, Bloom, 1991, Valian, 1991). Nevertheless, the dropped subjects are not found at the same rate in all sentences. There are pragmatic reasons, such as the informativeness and the recoverability of the subject DPs, that influence the pattern of omission in the spontaneous speech (Serratrice, 2005, Serratrice \& Sorace, 2003). However, the pragmatic principles at work in the information structure operate within the boundaries imposed by grammar (Serratrice \& Sorace, 2003). In section 3 we will show that the pattern of distribution of overt subjects depends on the lexical-syntactic class of the verbs they are found with. The loci of generation of the subjects within the VP shells (external /internal argument) influence the likelihood that a subject DP is overt. In section 4 we will consider how the syntax of pre and post verbal overt position of the subjects influence the pattern of distribution of overt elements. We will show that the the person $\left(1^{\text {st }}\right.$ and $2^{\text {nd }}$ person vs. $3^{\text {rd }}$ person) and the definiteness of the subject DPs play a central role in the appearance of overt postverbal subjects. This will lead us to propose that a subset condition is at work with indefinite subjects, especially in the earliest stages of the acquisition of Italian in section 5. Section 6 is devoted to some conclusive remarks: the Lexical Parameterization Hypothesis is internal structure of the grammar and represent a powerful cognitive mechanism in the acquisition of language.

\section{Pro Drop Parameter}

Italian is a null subject language. The central idea is that languages allow pro drop to the extent that their verbal agreement paradigm expresses the $\varphi$-features necessary for local 
recovery of the content of dropped arguments (see Taraldsen, 1978, Rizzi, 1986 among others). Italian allows null subjects due to the rich verbal morphology that permit their identification through the overt features of person and number.

Children from the very early stage correctly fix the pro-drop parameter (Lorusso, Caprin \& Guasti, 2005, Serratrice, 2005, Hyams, 2007, Orfitelli, 2008). Early null subjects in Italian have been a matter of investigation especially in a comparative perspective with English. It is well known (Hyam, 1986, Bloom 1990, Valian 1991, Rizzi, 1993/1994, among others) that young children learning English may omit referential subjects, albeit English is a non-pro-drop language. Valian (1991), for instance, compared the percentage of early null subjects in English with Italian productions. She found out that while in English early null subjects are the $30 \%$ in Italian they are the $70 \%$. The difference in ratio between the two languages was taken by Valian as a proof of the fact that the two types of null subjects were linked to different phenomena.

Different studies have focused on the distribution of null subjects in the spontaneous speech of Italian learners (Lorusso, Caprin \& Guasti, 2005, Serratrice 2005). Children from the very early stage correctly fix the pro-drop parameter. In Table 1 we report the data from Lorusso (2014) on the longitudinal corpus of spontaneous productions of four Italian children aged between 18 and 36 months (Calambrone corpus (Cipriani et al, 1989): Diana, Martina, Raffaello, Rosa. CHILDES database, MacWhinney \& Snow,1985): the production of null subjects is similar between adults and children (as also in Lorusso 2014, Serratrice 2005).

Table 1. General data about the distribution of Null /Overt subjects across children and adults (Lorusso, 2014)

\begin{tabular}{llllll}
\hline & \multicolumn{3}{l}{ Null Subjects } & \multicolumn{3}{l}{ Overt Subjects } \\
\cline { 2 - 6 } Diana & Number & Percentage & Number & Percentage & Total num. \\
\cline { 2 - 6 } Martina & 430 & $71,67 \%$ & 170 & $28,33 \%$ & 600 \\
Raffaello & 471 & $76,79 \%$ & 183 & $33,21 \%$ & 551 \\
Rosa & 594 & $77,14 \%$ & 176 & $22,86 \%$ & 770 \\
\hline Children & 1863 & $73,40 \%$ & 675 & $26,60 \%$ & 2538 \\
\hline Adults & 688 & $73,50 \%$ & 248 & $26,50 \%$ & 936 \\
\hline
\end{tabular}

Besides the general data in Table 1, the distribution of overt/null subjects in Italian has often been claimed to be determined by the pragmatics. Serratrice (2005) found out that children, after the MLUW stage of 2.0, use null and overt subjects in a pragmatically appropriate way: she catalogued subjects on the basis of their informativeness. The subjects that are the most informative are realized overtly and conversely those that are the least informative are null. She investigated three parameters of informativeness: 1) the informativeness of the person morphology: $3^{\text {rd }}$ person subjects are more likely to be realized overtly than first or second ones $^{1}$; 2) the activation state of referents ${ }^{2}$; 3) disambiguation of the referent ${ }^{3}$.

\footnotetext{
${ }^{1}$ We will argue that the split between $1^{\text {st }} / 2^{\text {nd }}$ person vs. $3^{\text {rd }}$ person is a grammatical and cognitive split and not only a pragmatic one (see section 3 for data and discussion).
} 
By the point of view of the acquisition of grammar, data like the ones in Table 1 can confirm that children use the null pro element early on, since the Italian rich verbal morphology permit their identification through the overt features of person and number. In other words, the Empty Projection Principle EPP (Chomsky,1981) is satisfied from the very first stage of the acquisition of Italian by the presence pf the null pro element. The discussion about the existence of pro has been a central topic in recent year (Barbosa, 1995, Nicolis,2005, Holmberg, 2005 among others) especially within the minimalist framework of Chomsky (1995). Ruling out the presence of pro is under the scope of the present work, but in our respect the inflection of the finite verb has a role both in identifying the phi -features of the referential subjects and to satisfy the EPP principle in language in Italian.

In the terms of Manzini \& Savoia (2007), the EPP property corresponds to a D(efiniteness) closure requirement: the subjects DP or the finite verb morphology have the denotational content $\mathrm{D}$ (efiniteness) ${ }^{4}$. If we use the $\mathrm{D}$ (efinitiness) feature we can define the pro drop parameter as how different languages realize this feature (Manzini \& Savoia, 2007). The D position of the sentential I domain can be lexicalized by a specialized head (such as subject clitics in northern Italian dialects), by a full noun phrase (English) or by either a specialized head or a full phrase (French). By contrast, in a language like Italian the D position of the sentential I domain is not lexicalized, while the D argument is lexicalized only at the morphological level by the inflection of the finite verb.

In terms of the parametric condition on the lexicalization of the D properties, Manzini \& Savoia (2007) propose a schematization like in (1). The divide between (a) and (b) in (1) corresponds to the classical divide between null subject languages and non-null subject ones.

(1) Lexicalization of the D properties of the sentential I domain:

a. i by clitic (e.g. northern Italian dialects)

ii by clitic or noun phrase (e.g. Ladin dialects, French)

iii by noun phrase (e.g. English)

b. no lexicalization (e.g. Italian)

In our respect the pro drop parameter can be restated in the terms of Lexical Paremetrization: the parameter is given depending on how the D feature are lexicalized. So, Italian children seem to acquire early on that the $\mathrm{D}$ feature are given. Nevertheless, the distribution of overt subjects in Italian is not homogeneous for every syntactic frames (Serratrice 2005, Lorusso, 2007, 2014): other lexical and morpho-syntactic features, which are in a Subset relation to the general pro drop (D) parameter, influence the distribution of the overt subjects. The verb classes, the scope discourse semantics implied by the pre or post verbal position of the overt subjects, the person morphology and the (in)definiteness of the subject DPs are the lexical(-syntactic) features that we will consider in the next sections. We will start by

\footnotetext{
$21^{\text {st }}$ and $2^{\text {nd }}$ person referents are always active by definition, while 3rd person are inactive/semi-active referents. (see Serratrice 2005, Serratrice \& Sorace 2003).

$33^{\text {rd }}$ person active referents with more than one antecedent are more likely to be be realized overtly than 3rd person unanmbiguous active referents.

${ }^{4}$ Following Manzini \& Savoia (2005, 2007, 2011) D is, in fact, the same category that we find in the highest position of nominals, where so called definite articles are inserted.
} 
showing in the next section that verb classes imply different use of overt subject both in adults and children's spontaneous speech.

\section{Null Subjects and Verb Classes}

The general data about overt null subject in the spontaneous speech shows that children fix the pro drop parameter early on: that is, they omit subjects at the same rate of the adults. However the distribution of overt subjects is not uniform across all the sentences of the spontaneous speech. The first 'subset' that we analyze is the verbal class. We differentiate verb classes for the projection of an external argument in the $v \mathrm{P}$. Unaccusative do not project external arguments (2), while unergatives (3) and transitives (4) do project an external argument in spec $v \mathrm{P}$.

(2) Unaccusatives

$$
\left[v \mathrm{vP} \_v[\mathrm{vP} \mathrm{DP}[\mathrm{vP} \mathrm{V} \mathrm{XP}]]\right]
$$

(3) Unergatives

$$
\text { [vP DP } v \text { [vp DP [vP V XP]] ] }
$$

(4) Transitives

$$
\text { [vP DP } v \text { [vp DP [vP V XP]] ] }
$$

External arguments are not true arguments (Pylkannen, 2002, Kratzer, 1996). In other words, Pylkkanen and Kratzer argue that the external argument is not introduced by the verb, but by a separate predicate, which Kratzer calls 'Voice' 5 . Voice is a functional head denoting a thematic relation that holds between the external argument and the event described by the verb; it combines with the VP by a rule called Event Identification. Event Identification allows one to add various conditions to the event that the verb describes; Voice, for example, adds the condition that the event has an agent (or an experiencer or whatever one consider possible thematic roles for external arguments). Verbs are supposed to be parameterized in the lexicon whether they project an external argument or not. Children (and adults) show a systematic behaviors depending on whether the subject is an external argument or an internal argument. In Table 2 we report the data of Lorusso (2014) about the distribution of overt subjects across verb classes in children and adults.

Table 2. General data about the distribution of Overt subjects across verb classes in children and adults' productions (absolut numbers and percentage) (Lorusso,2014)

\begin{tabular}{llllllll}
\hline & \multicolumn{3}{l}{ Overt Subject across Verb Classes } \\
\cline { 2 - 7 } & \multicolumn{2}{l}{ Unergatives } & \multicolumn{2}{l}{ Transitives } & \multicolumn{2}{l}{ Unaccusatives } \\
\cline { 2 - 7 } & N. & $\%$ & N. & $\%$ & N & $\%$ \\
\hline Diana & 12 & 23,53 & 113 & 26,40 & 45 & 37,19 \\
Martina & 24 & 26,97 & 115 & 32,67 & 44 & 40,00 \\
Raffaello & 22 & 25,00 & 70 & 18,23 & 54 & 37,24 \\
Rosa & 11 & 26,19 & 109 & 19,43 & 56 & 33,53 \\
\hline
\end{tabular}

\footnotetext{
5 We represent Voice as a vP following Chomsky (1995).
} 


\begin{tabular}{lllllll}
\hline Children & 69 & 25,56 & 407 & 23,59 & 199 & 36,65 \\
\hline Adults & 35 & 39,77 & 129 & 20,00 & 84 & 41,38 \\
\hline
\end{tabular}

The general results in Table 2 show a tendency in both adults and children in produce less overt subjects with transitives and unergatives than with unaccusative. Children significantly $(\mathrm{p}<0,05)$ produce more overt subjects with unaccusative than with other verb classes $(\chi 2=$ $36,21 \mathrm{df}=2$ for P-Value $=0.00001)^{6}$. Each verb is stored in the lexicon with the information on whether it projects an external argument or not. The lexical information about verb class influences the syntactic configuration of the VP shells and has an effect on the pattern of distribution of overt subjects for both children and adults. Children seem to be sensitive to the lexical parameterization of verbs. But why should the verb class influence the pattern of distribution of overt subjects? Our hypothesis is that the lexical parametrization of verbs has an effect on the syntactic derivation and interacts on the one side with the position of the overt subjects and on the other with the morpho-syntactic features of the overt subject DPs. In order to confirm this general hypothesis, we will check the position (preverbal or postverbal) of overt subjects in the spontaneous speech, since each lexical-syntactic verb class involves different syntactic derivation for pre or post verbal overt subjects.

\section{Subject Position}

Following the formulation of the pro-drop parameter of Rizzi (1982, 1986), a pro-drop language, like Italian, also allows: 1) the possibility of free inversion of the subject and 2) the possibility of extracting a subject across a that-type complementizer. For the purpose of the present analysis we will focus mainly on the fata about free inversion in Italian. For what concerns the relation between the null subject parameter and the free inversion, different authors (Gilligan 1987, Homlberg, 2005, Newmeyer 2005, Nicolis 2005, Manzini \& Savoia 2007, D'alessandro 2014 among others) have shown that the null subject parameter and the free inversion of the overt subjects are independent or at least they stand in a subset relation (Manzini \& Savoia 1997, 2007). Children have already acquired that Italian is a null subject language (Table 1), since the $\mathrm{D}$ feature are lexicalized at the morphological level by the inflection of the finite verb. Internal arguments, as the subject of unaccusatives, are more likely to be produced overtly (Table 2). But are they produced in a preverbal or postverbal position? On the one side, the postverbal subject may be read (Cinque,1993, Zubizarreta, 1998) in the scope of the Nuclear Stress Rule and Focus: in a language like Italian any inverted D element closes off the focus domain. On the other side, the lexicalization of the preverbal subject, which in Italian, by the hypothesis of Manzini \& Savoia (2007) in (1), does not satisfy a syntactic requirement on the D position of the inflectional domain, corresponds to its interpretation as a topic. So while the postverbal subject receives a focused reading, the preverbal subject is included within the topic material of the sentence. When children use preverbal and postverbal subjects are lexicalizing the scope discourse semantic properties of topicalization and focalization respectively.

\footnotetext{
${ }^{6}$ If we look at each child, we notice that the pattern of more overt subjects with Unaccusatives is confirmed: the data is statistically relevant for Diana $(\chi 2=6,04$; $\mathrm{df}=2$ for P-Value $=0.048801)$, Raffaello $(\chi 2=21,16$; $\mathrm{df}=2$ for $\mathrm{P}$-Value $=$ $0.000067)$ and Rosa $(\chi 2=14,8$; $\mathrm{df}=2$ for $\mathrm{P}$-Value $=0.000611)$, while for Martina there is a strong tendency although not statistically relevant, since it is relevant at $\mathrm{P}<0.10(\chi 2=3,9$; $\mathrm{df}=2$ for P-Value $=0,142274)$.
} 
Lorusso (2014) checked whether children acquire early on the free inversion and if it is linked to the verb classes and their VP shells. In Table 3 we report the overall data (Lorusso 2014) about the percentage of preverbal and postverbal subjects across verb classes. We can see that the general tendency is producing preverbal subjects SV with unergatives and transitives and postverbal subjects with unaccusatives.

Table 3. General data about the distribution of postverbal and preverbal subjects across verb class in both Italian children and adults’ spontaneous production (Lorusso 2014)

\begin{tabular}{lllllll}
\hline & \multicolumn{2}{l}{ Overt Subject Position across Verb Classes } \\
\cline { 2 - 7 } & \multicolumn{2}{l}{ Unergatives } & \multicolumn{3}{l}{ Transitives } & \multicolumn{2}{l}{ Unaccusatives } \\
\cline { 2 - 7 } Diana & SV & VS & SV & VS & SV & VS \\
\cline { 2 - 7 } Martina & $19(58,3 \%)$ & $5(41,7 \%)$ & $113(57,4 \%)$ & $84(42,6 \%)$ & $12(26,7 \%)$ & $33(73,3 \%)$ \\
Raffaello & $21(95,5 \%)$ & $1(4,5 \%)$ & $45(64,3 \%)$ & $25(35,7 \%)$ & $20(37 \%)$ & $34(63 \%)$ \\
Rosa & $8(72,7 \%)$ & $3(27,3 \%)$ & $77(70,6 \%)$ & $32(29,4 \%)$ & $21(37,5 \%)$ & $35(62,5 \%)$ \\
\hline Children & $55(79,7 \%)$ & $14(20,3 \%)$ & $319(65 \%)$ & $117(35 \%)$ & $69(34,7 \%)$ & $130(65,3 \%)$ \\
\hline Adults & $29(76,7 \%)$ & $6(20,3 \%)$ & $81(71,3 \%)$ & $48(28,7 \%)$ & $36(34,7 \%)$ & $48(65,3 \%)$ \\
\hline
\end{tabular}

The general data is quite clear: all children and adults show a pattern of preferential SV order with unergatives and VS for unaccusatives. Furthermore the percentages are very similar: both children and adults use in around the $70 \%$ of cases preverbal subjects when it is projected in the external argument position, while in the $65 \%$ of cases, postverbal subjects when it is projected in a direct object position. This distribution is statistically relevant for Children for $\mathrm{p}<0,05(\chi 2=41,80107122 \mathrm{df}=1 \text { for P-Value }=0.00001)^{7}$ and Adults $(\chi 2=$ $15,948 \mathrm{df}=1$ for $\mathrm{P}-$ Value $=0.00001)$.

Preverbal topicalized overt subjects are found with all verb classes. Unaccusatives are also produced with preverbal subjects, albeit fewer, showing that the Unique Check Constraint (UCC) Wexler (1999) does not apply: children are able to move outside the $v \mathrm{P}$ domain the intermal subject $\mathrm{DP}^{8}$.

Postverbal focused overt subjects, once more are found with all verb classes, but the higher number with unaccusatives suggest that these postverbal subjects may be left in situ. Following the original analysis of Belletti (1988), the position of licensing of the Object (an AgrOP position) is available. The case assigned in this position is not a proper nominative, but in terms of Belletti (1988) it is a partitive: the verb selects an indefinite meaning for the argument in internal argument position. In more recent analysis (Belletti, 1988, 2001, 2004, Bianchi \& Belletti, 2014) Belletti proposes that the postverbal subjects with unaccusatives are licensed in situ through a Functional projection F that carries [gender] and [number] probe,

\footnotetext{
${ }^{7}$ Each child show a statistically relevant preference $(p<0,05)$ for preverbals with unergatives and postverbals with unaccusatives: Diana $(\chi 2=4,275 \mathrm{df}=1$ for P-Value $=0.038677)$, Martina $(\chi 2=11,39 \mathrm{df}=1$ for P-Value $=0.000738)$, Raffaello $(\chi 2=9,446538893 \mathrm{df}=1 \quad$ for P-Value $=0.002116)$ and Rosa $(\chi 2=4.6476 \mathrm{df}=1$ for P-Value $=0.038677)$.

${ }^{8}$ Following Borer \& Wexler (1987) and more recently Wexler (1999) and Hirsch \& Wexler (2007) children's problems with passive or raising predicates are due to a deficit in the creation of an A chain or, in more minimalist terms, children may interpret vP as a phase so that at spell out they are not able to raise Subject DPs for passives and unaccusatives. For a a discussion on the problems with the A chain deficit hypothesis and the UCC with unaccusatives see Becker (2014) and Lorusso (2014)
} 
independent of the I layer. This functional projection FP is a probe for the object F agrees (probe) in gender and number with the internal object and then is probed by the number agreement of the finite verb I.

(5)

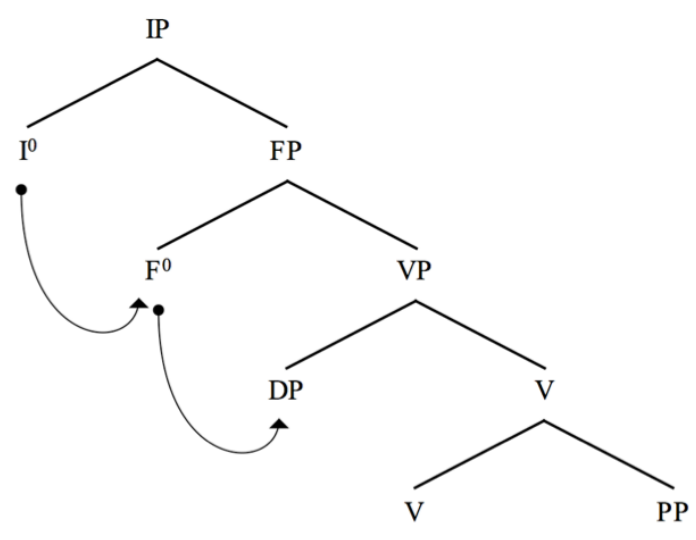

Due to characteristics of the agree mechanism of this postverbal position, nominative case is not assigned since the VP barrier blocks it. The features assigned by the FP in the VP periphery assign only an indefinite reading (6) since these postverbal subjects represented a property of the event denoted by the Unaccusative verb and not a mere participant.

(6) All'improvviso è entrato un uomo /*l'uomo/*ogni uomo dalla finestra.

Suddenly is entered a man/*the man/ *every man from the window

(Bianchi \& Belletti, 2014)

Manzini \& Savoia $(2007,2011)$ analogously proposes that postverbal subject may undergo some (in)definiteness restrictions and depending of the split of definiteness different pattern of agreement (as in Sardinian, Manzini and Savoia 2005, 2007) will be back on their analysis in section 4. In order to understand the subset relation instantiated by the different lexical parameters that have a role in the distribution of overt subjects we now introduce the concept of informativeness that is encoded in the subject DPs which interacts with the discourse semantic interface of focus and topic: that is, the person morphology. Person morphology has a preferential pattern of distribution depending on the position of the overt subjects and consequently, as seen above, on the verb class. The informative status of $1^{\text {st }}$ and $2^{\text {nd }}$ person vs. $3^{\text {rd }}$ person interacts with the lexical parametrization of verb classes.

\subsection{Person Morphology and Overt Subject}

Different authors have showed that person marking across languages undergoes some morpho-syntactic pattern linked to the referential status of the person (Benveniste, 1966, Harley \& Ritter, 2002 Bobalijk, 2008, Manzini \& Savoia 2005,2007, 2011, Legendre, 2010, 
among others). In our respect, it is worth to remark that languages are sensitive to the person split between $1^{\text {st }}$ and $2^{\text {nd }}$ singular person and $3^{\text {rd }}$ person ${ }^{9}$.

According to Manzini \& Savoia (2005, 2007, 2010, 2011), the person split, in its various manifestations, depends on the fact that the speaker and the hearer ( $1^{\text {st }}$ and $2^{\text {nd }}$ persons) are anchored directly in the universe of discourse, independently of their role within the event; on the other hand, non-participants in the discourse ( $3^{\text {rd }}$ persons) depend directly for their characterization on the position assigned to them within the structure of the event.

So $1^{\text {st }}$ and $2^{\text {nd }}$ persons are discourse anchored variables. In our respect they are easily recoverable from the universe of discourse. $3^{\text {rd }}$ persons are event anchored variables. They are event participants but they are not -participants in the discourse, so they are mainly recoverable by the linguistic sentence context. In the distribution of overt subjects in Italian we expect that $1^{\text {st }}$ and $2^{\text {nd }}$ person subjects are omitted more than $3^{\text {rd }}$ person subjects, since discourse anchored participants are more recoverable by the discourse than $3^{\text {rd }}$ person subjects.

Serratrice (2005) (as Allen,2000, Serratrice \& Sorace, 2003 among others) defines $1^{\text {st }}$ and $2^{\text {nd }}$ overt subjects as uninformative since they can be recovered by the discourse. $3^{\text {rd }}$ person subjects are defined informative since there is no discourse cue to identify them. She finds very clear results: after the MLUW stage of 2.0, $3^{\text {rd }}$ person (informative) overt subjects were produced two times more than of 1st or 2nd (uninformative) person subjects. We checked in the same corpus and we analyzed the spontaneous speech of the parents and the caregivers (Calambrone corpus (Cipriani, et al 1989): CHILDES database. MacWhinney \& Snow, 1985). In the chart in Figure 1 we resume the results about the production of overt subject depending on the person in the adults 'spontaneous speech. Infomative $3^{\text {rd }}$ person subjects are produced overtly in the $33 \%$ of the sentences, while uninformative ones $\left(1^{\text {st }}\right.$ and $2^{\text {nd }}$ person are produced overtly only in the $17 \%$ of the sentences.

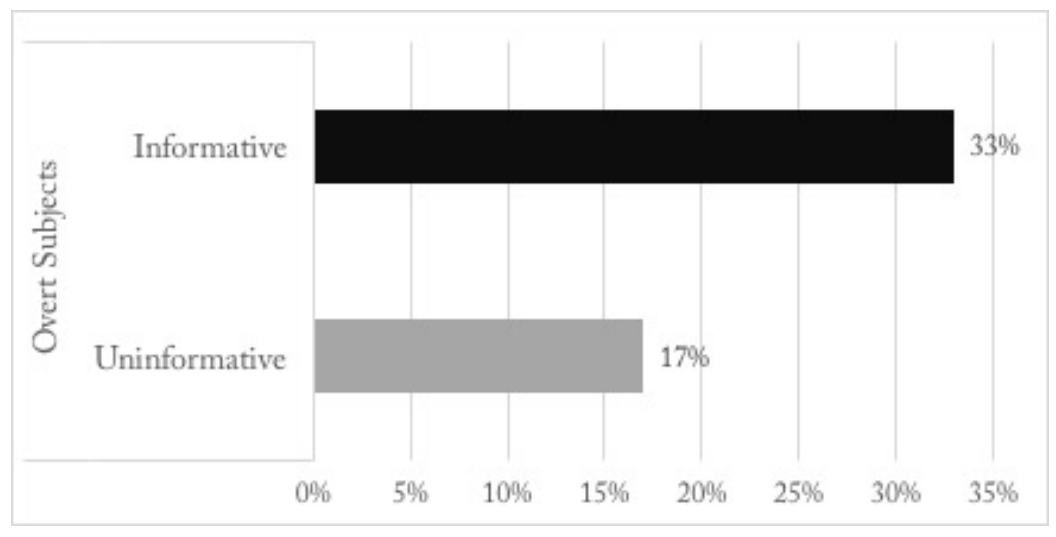

Figure 1. General data about the distribution of overt informative ( $3^{\text {rd }}$ person) and uninformative ( $1^{\text {st }}$ and $2^{\text {nd }}$ person) subjects in the spontaneous production of Italian adults

\footnotetext{
${ }^{9}$ Manzini \& Savoia 2007 showed that the person split is found, for example, in the morphological make-up (gender and Case distinctions)or in the agreement properties of the object clitics in Italian and the subject clitic in Northern Italianb dialects or in the or in the lexical selection involved by the auxiliary selection in many Italian dialects.
} 


\section{MInstitute Macrothink}

Then we checked we if there was any difference for the person of the overt subjects depending on the verb class. Children seem to use more informative subjects with unaccusatives. In Figure 2 we report the data about the distribution of the person of the overt subjects across the verb classes.

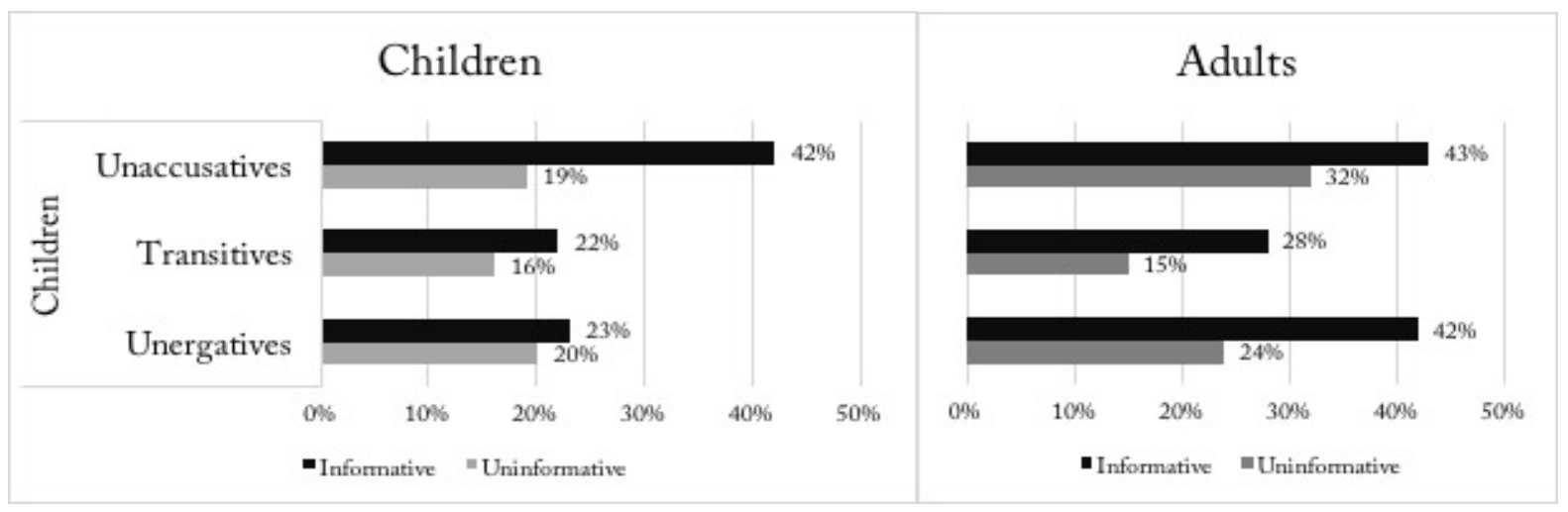

Figure 2. General data about the distribution of overt informative ( $3^{\text {rd }}$ person) and uninformative ( $1^{\text {st }}$ and $2^{\text {nd }}$ person) across verb classes subjects in the spontaneous production of Italian children and adults

While adults use more informative subjects with both unergatives and unaccusatives, children show a strong preference in using $3^{\text {rd }}$ person informative subject just in the case of internal argument. The verb class seems to influence the co-occurrence with $3^{\text {rd }}$ person overt subjects. The lexical parametrization of verbs (whether they project an external or an internal argument) seems to influence the general distribution of overt/null subjects (as in Table 2) on both children and adults. However, children, not adults, use more $3^{\text {rd }}$ person overt subjects just with the internal arguments of the unaccusatives. But why should the argument structure of unaccusatives influence the appearance of more informative overt subjects? The answer is linked to the preferred postverbal position found for overt subjects with unaccusatives (see Table 3). We have been arguing that postverbal subjects represent are focalized and represent new information in a scope discourse semantic perspective. We checked the person morphology of the postverbal subjects in the spontaneous speech and we found, in fact, that both children and adults use almost $3^{\text {rd }}$ person for postverbal subjects with unaccusatives, but not with other verb classes. In Figure 3 we report the data about the distribution of $3^{\text {rd }}$ person postverbal subjects across verb classes in the spontaneous speech of adults and children. 
3rd person postverbal subjects and verb classes

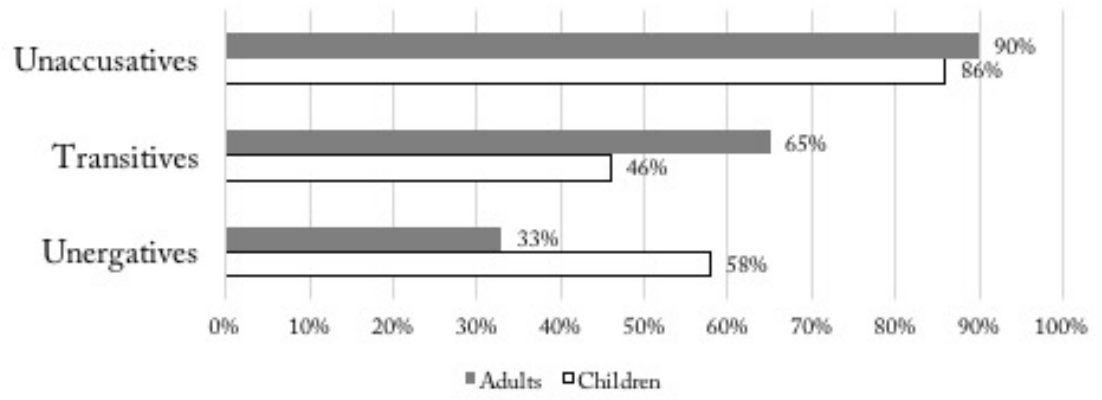

Figure 3. General data about the distribution of overt informative ( $3^{\text {rd }}$ person) postverbal subjects across verb classes in the spontaneous production of Italian children and adults

So the preferential position of overt subjects found with the different verb classes shows that the scope discourse semantics overlap the aktionsart of verbs. External (agentive) argument are more likely to be old information and they are expressed preverbally or omitted, they are more likely to be recovered by the context: for the very same reason in children's speech informative and uninformative person are found at the same rage for the subjects of unergatives and transitives (Figure 2). Internal arguments are more likely to be expressed overtly and in postverbal position, they are part of the eventive structure of the verb and they are strictly linked to the linguistic context, they can not be inferred by the discourse. Both children and adults, in fact, use mainly $3^{\text {rd }}$ person DPs for postverbal subjects with unaccusatives (Figure 3).

Nevertheless, the $3^{\text {rd }}$ person postverbal subjects are not linked only to the scope disourse semantic but other grammatical features seem to be involved. While $1^{\text {st }}$ and $2^{\text {nd }}$ person are mainly definite DPs $3^{\text {rd }}$ person DPs can be indefinite. The split of definiteness can have a role in explaining the pattern of early overt subjects in the Italian children's spontaneous speech (which is different from adults' productions): unaccusatives are found with more $3^{\text {rd }}$ person subjects than other verb classes. Next section is devoted to some data and considerations on the indefinite postverbal subjects in children's speech and to the parametric variation that implies the split of definiteness which in a subset relation to the pro drop parameter.

\section{5. (In)definiteness of the postverbal subjects}

The data of the preferential use of $3^{\text {rd }}$ person overt subjects with unaccusatives is linked to the argument structure of unaccusatives. The internal argument is part of the event expressed by the predicate: it measures out the event and it determines an eventive closure (Ritter \& Rosen 1998, Mateu, 2002, among others). In other words, the theme or the patient arguments are 'stucked' in the eventive relation predicated by the verbal head. Postverbal subjects with unaccusatives are a crucial element in the configuration of the unaccusative verb class: their (in)definiteness plays a central role in the definition of the the eventive structure.

Chomsky (1995), about the expletive construction in a non pro drop language like English points out that a definite associate is connected to a different interpretation than an indefinite 
one. Thus an indefinite associate gives rise to the typical existential reading in (7a), while a definite associate gives rise to the list interpretation, as in (7b). Furthermore, in English the expletive constructions are restricted mainly to unaccusatives.

(7) a There is somebody outside

b There is John for a start

For what concerns Italian, postverbal indefinite subjects are possible with all verb classes, but just with unaccusatives they may represent a closure of the event denoted by the predicates. Lorusso (2014) found out that children in the corpus of spontaneous speech of the earliest stage of acquisition of Italian (18-36 months), use indefinite postverbal subjects just with unaccusatives. They never use a postverbal indefinite DP with unergatives and transitives as in Table 4. While adults do use indefinite postverbal subjects (in few cases) also with other verb classes.

Table 4. Absolute numbers and percentage of indefinite postevrbal subjects across verb classes (Lorusso 2014)

\begin{tabular}{lllll}
\hline \multicolumn{3}{l}{ Distribution of Definite Subjects in SV or VS order accross Verb Classes } \\
\hline & \multicolumn{3}{l}{ Preverbal Subjects } & \multicolumn{2}{l}{ Postverbal Subjects } \\
\cline { 2 - 5 } & Indefinite & Definite & Indefinite & Definite \\
\cline { 2 - 5 } Unergative & $2(4 \%)$ & $55(96 \%)$ & $\mathbf{0 ( 0 \% )}$ & $14(100 \%)$ \\
Unaccusatives & $3(4 \%)$ & $70(96 \%)$ & $23(18 \%)$ & $130(82 \%)$ \\
Transitives & $3(1 \%)$ & $290(99 \%)$ & $\mathbf{0 ( 0 \% )}$ & $117(100 \%)$ \\
\hline
\end{tabular}

Similar results are found also in a sentence repetition task (Vernice \& Guasti, 2014) with older children (4;2 to 5;11 years of age): when children were presented with un unaccusative verb and indefinite subject, they showed a preference in repeating it in a VS order. The same pattern was not found with definite subject and with other verb classes.

The learning component of the Subset Principle, "which orders parameter values according to the subset relations of the languages that the values generate... (Manzini \& Wexler, 1987, pp. 414)" states that children must pick up the smaller subset of the language. Italian infants assume that the verb inflection introduces the D argument and satisfies the EPP principle. Then, with postverbal subjects with unaccusatives they pick up the smaller subset of the language, “..the variable introduced by the verb inflection is existentially closed [...] the identification of the variable by the argument in focus requires the argument itself to be compatible with existential quantification. An indefinite noun is straightforwardly predicted to satisfy this requirement, as it is itself in the scope of existential closure" (Manzini \& Savoia 2007:75). So children set the agree mechanism with postverbal indefinite subjects just for unaccusatives that project internal arguments. Recall that following also Belletti (2004) and Bianchi and Belletti (2014) these postverbal subjects represented a property of the event denoted by the unaccusative verb and not only a participant. The subset principle at work is that indefinites are allowed in postverbal position just when they denote a property of the event or are under the scope of the existential closure represented by the D properties of the 


\section{MlMacrothink}

International Journal of Linguistics

ISSN 1948-5425

2017, Vol. 9, No. 6

verbal morphology (Manzini \& Savoia 2007): that is, when they are internal argument of the verb and they represent a predication relation rather than a chain identification relation.

This kind of data follows by a real parametric option found across Romance languages. There is, in fact, a parametric variation involving null subject languages: the presence or absence of agreement of the I with postverbal subjects depending on the (in)definiteness of the postverbal DP. Manzini \& Savoia $(2007,2011)$ reports that data coming form many dialects which display (some degree of) interaction between the agreement pattern and the (in)definiteness of the postverbal subject. In (8) we report about the dialect of Monreale where a definite postverbal plural subjects agree with the I (8a) while an indefinite postverbal subjects do not (8b). Auxiliary selection may also vary depending on the instantiation for the predicative relation instantiate by the indefinite subject: in the Sardinian variety of Orroli the agreeing postverbal definite subject is introduced by the be auxiliary (9a) while the non-agreeing post verbal indefinite subject is introduced by the have auxiliary (9b).

(8) Montereale (Friuli)

a.i veN i no fi'oi
ClS come the our children
'Our children come'
b. a 'veN ka'nais
ClS comes children
'Children come'

(9) Orroli

(Manzini \& Savoia 2007,pp.72)
a.funti e'niuzu is pittsik'kedduzu are come the children
'The children came'
b. dui a Be'niu pittsik'kedduzu here has come children 'Children came here'

(Manzini \& Savoia 2007, pp. 73)

Indefinite postverbal subjects agree ${ }^{10}$ with the $\mathrm{D}$ properties of the verb although there is no lexicalization of the $\mathrm{D}$ properties within the postverbal indefinite DP (no chains identification): the postverbal indefinite can be the existential closure of the inflectional D morphology. The predicative relation between the unaccusative verbs and their internal argument is taken by children as the only syntactic environment where indefinite postverbal subject can be inserted. With unergatives and transitives there is no such a predicational relation within the subject and the event denoted by the verb.

\footnotetext{
10 Or not, in languages like the ones in (8) and (9) where the absence of D properties within the postverbal DP may determin parametric variation on the agreement mechanism, for a detailed discussion on it see Manzini \& Savoia 2007, 2011.
} 
Children have set the pro-drop parameter: D properties (1) of the sentential I domain have no lexicalization in Italian other than the inflectional morphology of the verbs. Then, the argument structure of verbs influences the distribution of the overt subjects: the predicative relation between unaccusative verbs and their internal argument is the only syntactic environment where children allows overt indefinite postverbal subject since the event expressed by the unaccusative requires an existential quantification. The argument structure of unaccusatives and the indefiniteness of DPs defines a restrictive subset for the distribution of overt postverbal subjects in child Italian.

\section{Conclusion}

In this paper we accounted for the distribution of early and adult null subjects following the statement of the Lecial Parametrization Hypothesis (Manzini and Wexler, 1987) The lexical parameterization hypothesis states that: "values of a parameter are associated not with a particular grammar but with particular lexical items” (Manzini and Wexler 1987: 424) by children. By the data we have reported in the present work we found out that children set early on the prod-drop parameter, formulated as in (1) that we repeat here in (10), in the sense that they do jot assign the D properties of the sentential to any lexical item other than the same inflectional morphology of the verb.

Lexicalization of the $\mathrm{D}$ properties of the sentential I domain:

a. i by clitic (e.g. northern Italian dialects)

ii by clitic or noun phrase (e.g. Ladin dialects, French)

iii by noun phrase (e.g. English)

b. no lexicalization (e.g. Italian)

Although children acquire early on the pro-drop parameter, it does not mean that the distribution of overt subject DPs is random. The lexical parameter associated with different lexical items intervenes in the creation of subset condition which allows to account for the distribution of overt subject in Italian. We have collected old and new data to account for the distribution of overt subjects as a reflex of different lexical parameters that interacts.

The first lexical parameter at work is linked to the verb classes. When the verb projects external argument the omission of the subject DP is favored in children's data, conversely when the verb projects an internal argument, subject DPs are more likely to be produced overtly (tab.2). The preverbal and postverbal position of overt subjects seems to be inherently linked also to their loci of generation within the VP shells: overt external argument are found preferentially in a SV order, while overt internal arguments are found preferentially in a VS order in the spontaneous speech of both Italian children and adults.

This pattern matches the scope discourse semantic interface requirements: preverbal subjects are topic-like information while postverbal subjects are focus-like information. Agentive subjects found with unergatives and transitives are more likely to be omitted and recovered by the discourse than theme and patient subjects found with unaccusatives which measures out the event and are recoverable. The data about the informativeness of the person of the subject DPs (Serratrice 2005) also confirms that theta roles assigned to the subject by each 
verb influence the pattern of omission. While external argument in children's spontaneous speech are found with both uninformative $\left(1^{\text {st }}\right.$ and $2^{\text {nd }}$ singular $)$ and informative ( $3^{\text {rd }}$ singular) person, internal subjects of the unaccusatives are preferentially $3^{\text {rd }}$ person DPs which are event related and not recoverable by the discourse. So informative persons are found with DPs that are focus-like: postverbal subject funs with unaccusatives, insfact, are mainly $3^{\text {rd }}$ person DPs (around 90\%).

The last lexical parameter is linked to the definiteness of the DP. Children produce indefinite postverbal subjects just with unaccusatives. In child Italian indefinite are allowed only when they are in the scope of the D properties and they are part of the eventive structure of the verb, that is when they are not derived through event identification (Pylkannen 2002, Kratzer 1996) as the external argument: they measure out (Ritter and Rosen, 1998) the event denoted by the verb and they allow a mechanism of agreement which does not involve the replication $D$ properties on the indefinite DP, language may vary on the agreement mechanism with the postverbal indefinite DPs.

Lexical parametrization seems to be a predictive and powerful mechanism to account for the acquisition od a language for two main reasons. First because the parameters seem to be associated not with a particular grammar but with particular lexical items. In our respect for the distribution of overt subjects different paremeter are set on lexical items: D properties on the verb morphology allow the omission of the subjects, the verb classes for the projection of the arguments and the definiteness of the DP influence the pattern of distribution of the overt subjects depending on the informativeness as it results by their morphos-syntactic properties.

Least but not last, the parameters associated with each lexical items defines some syntactic domains in a given language where lexical item are allowed (or not). They allow to have a subset of the sentences of the languages in which a given lexical item is allowed or banned. In our respect the interaction between verb classes and the (in)definitiness determines a subset within the Italian sentences. Children selects the value of a parameter that generates the smallest language that is compatible with the data (as for the Subset principle) so that indefinite postverbal subjects are found only with unaccusative.

\section{References}

Allen, S. (2000). A discourse-pragmatic explanation for argument representation in child inuktitut. Linguistics, 38(3), 483-521. https://doi.org/10.1515/ling.38.3.483

Barbosa, P. (1995). Null subjects. PhD dissertation: MIT.

Belletti, A. (1988). The case of unaccusatives. Linguistic Inquiry, 19, 1-34.

Belletti, A. (2001). Inversion as focalization. In A. Hulk \& J. Pollock, (ed.) Inversion in Romance and the theory of Universal Grammar, 60-90. Oxford University Press (OUP). https://doi.org/10.1017/s0022226702261988

Belletti, A. (2004). Aspects of the low ip area. In L.Rizzi (ed.). The structure of CP and IP. The Cartography of Syntactic Structures, 2, 16-51. New York: Oxford University Press. 
Benveniste, E. (1966). Problèmes de linguistique générale, Gallimard, Paris.

Bianchi, V., \& Belletti, A. (2014). Indefinite subjects of unaccusatives. Talk at the workshop "Specificity in the grammar. Form and Interpretation", held in Trento University of Trento, 12 February 2014.

Bloom, P. (1991). Subjectless sentences in child language. Linguistic Inquiry, (21), 491-504.

Bobaljik, J. (2008). Missing persons: a case study in morphological universals, The Linguistic Review, special issue Examples of Linguistic Universals, 25, 203-30. https://doi.org/10.1515/tlir.2008.005

Borer, H. (1984). Parametric Syntax, Foris, Dordrecht. https://doi.org/10.1515/9783110808506

Borer, H., \& K. Wexler. (1987). The maturation of syntax. In T. Roeper and E. Williams (eds) Parameter Setting. Dordrecht: Reidel. https://doi.org/10.1007/978-94-009-3727-7_6

Chomsky, N. (1981). Lectures on Government and Binding. Dordrecht: Foris. https://doi.org/10.1515/9783110884166

Chomsky, N. (1995). The Minimalist Program. Cambridge Mass.:MIT Press. https://doi.org/10.7551/mitpress/9780262527347.001.0001

Chomsky, N. (2001). Derivation by phase, in M. Kenstowicz (ed.), Ken Hale: A Life in Language.Cambridge, Mass.: MIT Press, pp. 1-52.

Cipriani, P., Pfanner, P., Chilosi, A., Cittadoni, L., Ciuti, A., ... Veneziano, E. (1989). Protocolli diagnostici e terapeutici nello sviluppo e nella patologia del linguaggio. Protocollo n. 1/84. Ministero della Salute della Repubblica Italiana: StellabMaris Foundation.

Gilligan, G. M. (1987). A cross linguistic approach to the pro-drop parameter. $\mathrm{PhD}$ dissertation: University of Southern California.

Harley, H., \& E. Ritter (2002). Person and number in pronouns: a feature geometric analysis, ms., University of Arizona and University of Calgary. https://doi.org/10.1353/lan.2002.0158

Hirsch, C., \& Wexler, K. (2007). The late acquisition of raising: What children seem to think about seem, in S. Dubinsky and B. Davies (eds.) New horizons in the analysis of control and raising. NY: Springer. https://doi.org/10.1007/978-1-4020-6176-9_3

Holmberg, A. (2005). Is there a little pro? Evidence from Finnish. Linguistic Inquiry, 36, 533-64. https://doi.org/10.1162/002438905774464322

Hyams, N. (1986). Language acquisition and the theory of parameters. Dordrecht: Reidel.

Hyams, N. (2007). Aspectual effects on interpretation. Language Acquisition, 14(3), 231-268. https://doi.org/10.1080/10489220701470992 


\section{Macrothink}

International Journal of Linguistics ISSN 1948-5425 2017, Vol. 9, No. 6

Kratzer, A. (1996). Severing the external argument from the verb. In J. Rooryck and L. Zaring (Eds.), Phrase Structure and the Lexicon, 109-137. Dordrecht: Kluwer. https://doi.org/10.1007/978-94-015-8617-7_5

Legendre, G. (2010). A formal typology of person-based auxiliary selection in Italo-Romance', in R. D’Alessandro, A. Ledgeway and I. Roberts (eds.), Syntactic Variation: the Dialects of Italy. Cambridge University Press, pp. 86-101.

Lorusso, P. (2007). The acquisition of aspect in 11 italian. In: Proceedings of the 2nd Conference of GALANA, A. Belikova, L. Meroni, \& M. Umeda, ed., pages 253-264. Somerville: Cascadilla Press.

Lorusso, P. (2014). Verbs in Child Grammar The Acquisition of the Primitive Elements of the VP at the Syntax-Semantics Interface. PhD Dissertation, Universitat Autónoma de Barcelona. Retrieved from http://www.tdx.cat/bitstream/handle/10803/283726/pl1de1.pdf?sequence=1.

Lorusso, P., Caprin C., \& Guasti, M. T. (2005). Overt subject distribution in early italian children,” in BUCLD 29 Proceedings Supplement. BU Boston,MA.: Online Publishing Retrieved from http://www.bu.edu/linguistics/APPLIED/BUCLD/supp29.html.

MacWhinney, B., \& Snow, C. E. (1985). The child language data exchange system. Journal of Child Language, (12), 271-296. https://doi.org/10.1017/s0305000900006449

Manzini, M. R. \& Savoia, L. M. (2011). Grammatical Categories. Variation in Romance Languages, Cambridge Studies in Linguistics:128. Cambridge: CUP. https://doi.org/10.1017/cbo9780511974489

Manzini, M. R., \& Savoia, L. M. (2005). I dialetti italiani e romanci. Morfosintassi generativa. Alessandria: Edizioni dell‘'Orso.

Manzini, M. R., \& Savoia, L. M. (2007). A Unification of Morphology and Syntax. London: Routledge. https://doi.org/10.4324/9780203968154

Manzini, M. R., \& Wexler, K. (1987). 'Parameters, Binding Theory and learnability'. Linguistic Inquiry, 18, 413-44.

Manzini, M.R. and Savoia, L.M. (1997). Null subjects without pro, UCL Working Papers in Linguistics, 9, 301-313.

Mateu, J. (2002). Argument Structure: Relational Construal at the Syntax Semantics Interface. $\mathrm{PhD}$ thesis, Universitat Autónoma de Barcelona.

Newmeyer, F. J. (2005). Possible and Probable Languages: A Generative Perspective on Linguistic Typology. Oxford: Oxford University Press. https://doi.org/10.1017/s0022226706254586

Nicolis, M. (2005). On pro-drop. PhD dissertation: Università degli Studi di Siena.

Orfitelli, R. M. (2008). Null subjects in child language: The competing roles of competence and performance. Master's thesis, UCLA, Los Angeles, California. 
Pylkkänen, L. (2002). Introducing Arguments. Ph.D. thesis, MIT. https://doi.org/10.7551/mitpress/9780262162548.001.0001

Ritter, E., \& Rosen, S. (1998). Delimiting events in syntax. In M. Butt \& W. Geudee, (ed.): The Projection of Arguments, 135-164. CSLI.

Rizzi, L. (1982). Issues in Italian Syntax. Dordrecht: Foris. https://doi.org/10.1515/9783110883718

Rizzi, L. (1986). Null-objects in italian and the theory of pro. Linguistic Inquiry, (17):501559.

Rizzi, L. (1993/1994). Some notes on linguistic theory and language development: The case of root infinitives. Language Acquisition, 3, 371-393. https://doi.org/10.1207/s15327817la0304_2

Serratrice, L. (2005). The role of discourse pragmatics in the acquisition of subjects in Italian, Applied Psycholinguistics, (26):437-462. https://doi.org/10.1017/s0142716405050241

Serratrice, L., \& Sorace, A. (2003). Overt and null subjects in monolingual and bilingual italian acquisition. In: Proceedings of the 27th Annual BUCLD, 2. Somerville: Cascadilla Press.

Taraldsen, K. T. (1978).On the NIC, Vacuous Application, and the That-t Filter, ms., MIT

Valian, V. (1991). Syntactic subjects in the early speech of american and italian children. Cognition, (40), 21-81. https://doi.org/10.1016/0010-0277(91)90046-7

Vernice, M. and M.T.Guasti, (2014). The acquisition of sv order in unaccusatives: manipulating the definiteness of the np argument, Journal of Child Language, 1-28. https://doi.org/10.1017/s0305000913000536

Wexler, K., \& Manzini, R. (1987). Parameters and Learnability in Binding Theory, in T. Roeper and E.Williams (ed.), Parameter Setting. Dordrecht: Reidel, 41-76. https://doi.org/10.1007/978-94-009-3727-7_3

\section{Copyrights}

Copyright for this article is retained by the author(s), with first publication rights granted to the journal.

This is an open-access article distributed under the terms and conditions of the Creative Commons Attribution license (http://creativecommons.org/licenses/by/4.0/) 